\title{
Labin ili izvedba undergrounda kao jedan od modusa otpora izolaciji/ periferiji'
}

Sažetak: Na primjeru istarskoga gradića Labina ilustriram na koji način izolacija, tzv. periferija može biti i izraz otpora u niši kulture. Kolektiv Labin Art Express (L.A.E. - pokretači: Dean Zahtila, pokojni Krešimir Farkaš, Graziano Kršić) inicijator je i voditelj fundamentalnoga projekta Underground City XXI - osnivanja podzemnoga labinskoga kulturnoga grada kao alternative postojećem, nadzemnom, heteronomnom Labinu, tj. stvaranja pravog grada 150 metara ispod površine zemlje, u podzemnim halama i tunelima isklesanim u živoj stijeni, koji spajaju Labin, Rašu, Plomin i Rabac, i to s ulicama, barovima, galerijama, bazenima, igralištima za djecu, trgovinama, restoranima, Muzejom rudarstva i industrije Istre. Pritom Labin možemo usporediti urbanoantropološki s Katowicama u kojima je 2018. godine održana najvažnija UN-ova konferencija o klimatskim promjenama nakon Pariškog sporazuma 2015. godine. Katowice su odabrane s jedne strane kao jedan od najzagađenijih dijelova Europe zbog eksploatacije ugljena, a s druge strane zbog svoje tranzicije iz rudarsko-industrijskoga u moderno industrijsko, gospodarsko, tehnološko i kulturno središte.

Ključne riječi: Labin Art Express, projekt Underground City XXI, antropologija rudarenja, Katowice, periferija kao izraz otpora

$\mathrm{Na}$ primjeru istarskoga gradića Labina ilustriram na koji način izolacija, tzv. periferija može biti i izraz otpora u niši kulture. No prvo nekoliko riječi o kolektivu Labin Art Express (L.A.E. - inicijatori: Dean Zahtila, pokojni Krešimir Farkaš, Graziano Kršić) s njegovim TransArtom - međunarodnim transdisciplinarnim umjetničkim festivalom i la-

\footnotetext{
${ }^{1}$ Rad je sufinancirala Hrvatska zaklada za znanost (,Naracije straha: od starih zapisa do nove usmenosti“, projekt IP-06-2016-2463).
} 
boratorijem. Dean Zahtila 1984. u Labinu otvara RE galeriju, jednu od prvih privatnih umjetničkih galerija u bivšoj Jugoslaviji. Godine 1991. s kiparom i pomorcem Krešimirom Farkašem osniva kulturno-umjetničko društvo (od 1998. udruga) Labin Art Express (od 2005. u imenu ima i XXI) čiji je predsjednik od osnivanja do danas. Od 1993. do 1996. direktor je Radija L.A.E. - prve potpuno nezavisne radijske postaje u Hrvatskoj. Godine 1994. zajedno s Massimom Savićem i Krešimirom Farkašem osniva multimedijalnu grupu Metal Guru, jednu od frakcija Labin Art Expressa. Inicijator je i voditelj fundamentalnog L.A.E.-ova projekta Underground City XXI - osnivanja podzemnoga labinskoga kulturnoga grada kao alternative postojećem, nadzemnom, heteronomnom Labinu, tj. stvaranja pravog grada 150 metara ispod površine zemlje, u podzemnim halama i tunelima isklesanim u živoj stijeni, koji spajaju Labin, Rašu, Plomin i Rabac, s ulicama, barovima, galerijama, bazenima, igralištima za djecu, trgovinama, restoranima, Muzejom rudarstva i industrije Istre, $\mathrm{i}$ to $\mathrm{u}$ kontekstu antropologije rudarenja. ${ }^{2}$

\section{L.A.E. - temeljni projekt Podzemni grad XXI}

L.A.E. (Labin Art Express) kao interdisciplinarna umjetnička udruga osnovan je na tragu underground kulture osamdesetih, razjasnili su njezini osnivači u svom programatskom tekstu Umjetnički credo L.A.E., publiciranom prigodom predstavljanja u zagrebačkom Muzeju suvremene umjetnosti 1992. godine na poziv povjesničara umjetnosti i kustosa Davora Matičevića. Bilo je to prvo javno samopredstavljanje L.A.E.-a i Kulturnog centra Lamparna. Zamišljeno je na način da se podzemne energije dovedu u previše racionalan Zagreb, odnosno, kako je to dokumentirano u monografiji o L.A.E.-u: „Kroz instalacije, performanse, dramske prikaze, izložbe i projekcije, procesiju ,rudara Zagrebom, glazbu sopaca te istarski gastro-happening, zbog kojeg je čitav event završio partijanjem u prepunom Muzeju do ranih jutarnjih sati - simulirana je ideja transformacije baštine bivših istarskih ugljenokopa Raša u Podlabinu u suvremeni kulturno-umjetnički kompleks pod nazivom KuC Lamparna.“3 Naime, 12. rujna 1998. u sklopu bivšeg

\footnotetext{
${ }^{2}$ Usp. Labin Art Express: 1992.-2012. (predgovor Viktor Zahtila, pogovor Branko Franceschi, autori fotografija Rajko Tasić i sur.) (Labin: Labin Art Express XXI, 2013). U poglavlju „Memorija ili ,nek se topi!““ etnolog i kulturni antropolog Andrea Matošević tematizira preživljavanje rudarskoga nasljeđa nakon gašenja podzemnih iskopa (Andrea Matošević, Pod zemljom: antropologija rudarenja na Labinštini u XX. stoljeću (Zagreb: Institut za etnologiju i folkloristiku - Sveučilište Jurja Dobrile u Puli, 2011)).

${ }^{3}$ Labin Art Express: 1992.-2012., 61.
} 
industrijskog kompleksa labinskog rudnika otvara se Lamparna kao prvi nezavisni i međunarodni kulturni centar u Hrvatskoj. Tako je kamen temeljac L.A.E.-a postavljen u derutnom i napuštenom rudarskom objektu spojenom na podlabinski šoht i zvanom Lamparna. Često se ističe kako su programi u Lamparni započeli još 1992. godine kada je L.A.E. ušao u bivše rudarske zgrade u centru Labina, a članovi pokrenuli i vlastitu radiostanicu Radio L.A.E. - kojoj je već 1996. oduzeta koncesija „zbog toga što su previše europska, a premalo hrvatska postaja“.4

Godine 2007. L.A.E. XXI uz potporu grada Labina započinje rekonstrukciju kompleksa Pijacal, ${ }^{5}$ koji uključuje zgrade i šoht, te projekt Podzemni grad/Underground City XXI. Istarska županija proglasila ga je „milenijskim županijskim projektom“, a sufinancirala ga je i Europska Unija. Temeljni je projekt tog underground kolektiva projekt Underground City XXI - osnivanje podzemnoga labinskoga kulturnoga grada kao alternative postojećem, nadzemnom Labinu. Njegov program čini pretvorba bivšeg rudnika ugljena u (Pod)Labinu (Pozzo Littorio) i Raši (Arsia), kako navode, ,jednog od najvećih tehnoloških dostignuća na području rudarenja u svijetu s početka 20. stoljeća, u futuristički podzemni grad, urbano-društvenu skulpturu u neprestanom stvaranju“. O fizičkoj se realizaciji projekta počelo razmišljati, kako to često ističe Dean Zahtila, tek nakon što je Rudarsko-geološko-naftni fakultet iz Zagreba po narudžbi Istarske županije godine 2000. završio studiju o izvedivosti projekta, koja je potvrdila da umjetnička utopija može postati i realnost. ${ }^{6}$ Ukratko, projekt Podzemni grad XXI formalno je započet 1998. otvaranjem Lamparne - budućega ulaza u Podzemni grad, tj. čekaonice za lift koji će nas odvesti 150 metara ispod zemlje. Inače, Lamparna je dobila ime po svojoj funkciji - mjestu za odlaganje i punjenje rudarskih lampi. Danas služi kao izložbeni prostor, mjesto održavanja radionica i koncerata te kao ured L.A.E. XXI. Od 2014. godine u kompleksu Pijacal održava se Industrial Art Biennial/Bijenale industrijske umjetnosti, koje ugošćuje domaće i međunarodne umjetnike čija su djela inspirirana industrijom, njezinom prošlošću, propašću ili

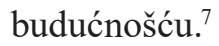

\footnotetext{
${ }^{4}$ Labin Art Express: 1992.-2012., 61.

${ }_{5}^{5}$ Rudarsko-industrijski kompleks Pijacal nalazi se u dijelu sjevernoga podnožja brežuljka na kojem je labinski Stari grad.

${ }^{6}$ U ovome se dijelu rada koristim fragmentima svoga teksta iz 2014; Suzana Marjanić, „Izvedba undergrounda,“ Zarez, br. 383 (2014): 41.

${ }^{7}$ Katarina Lamešić, „Branka Cvjetičanin, Delegacija, posjet Raši, Krapnu i Labinu, 20. svibnja 2017., izložba: Galerija Prozori, 6. - 20. lipnja 2017.,“ Narodna umjetnost, sv. 54, br. 2 (2017): 229-231.
} 
Godine 2012. pokreće se međuregionalni projekt mreže partnera multilateralnog klastera Rudnici kulture ${ }^{8}$ čija je ideja povezati rudarska mjesta bivše Jugoslavije te mapirati bivše i sadašnje rudnike radi određivanja njihova statusa i mogućnosti prenamjene njihova sadržaja. ${ }^{9}$

\subsection{Labin ili istarski Twin Peaks: dvojni grad}

Kao svojevrsna margina periferije u okviru kolektiva Labin Art Express donedavno je djelovala i multimedijalna umjetnica Xena L. Županić, koja danas uglavnom djeluje na milanskoj kontrakulturnoj sceni. Što se tiče biografskoga konteksta Xene L. Županić, glumice, redateljice, književnice, scenografkinje, modela, umjetnice performansa, valja istaknuti njezine vokoperformanse, $\mathrm{u}$ kontekstu njezine nedavno objavljene četvrte knjige Yztok Zapada ${ }^{10}$ koju ispisuje logocentričnom igrom metaforika i u kojoj, među ostalim, dokumentira margine grada, pa tako u tekstu „Labin@Twin Peaks“ ističe zlatne sedamdesete, „kada sva mjesta, svi toponimi u našoj malenoj domovini zovu se bez prisile, i bez ikakva materijalnoga osvajanja i nasilnoga krštenja, Peyton Place, refuggium peccatorum". U usporedbi sa zlatnim sedamdesetima umjetnica devedesete određuje platinastom atribucijom - „s agonijom na vrhuncu, raspadom u grimizu perverzije, kada sve postaje dvojno, dvojina svaka sa svojim vrhuncem, utvrđenim brežuljkom, odakle vidi se vrh nizine, podnožje stopala grada: Twin Peaks ili sijamsko tijelo s dvije glave, gornjom i donjom, starim i relativno novim gradom, socijalizmom i nekim neutvrđenim aristokratskim feudalizmom"."11

\footnotetext{
${ }^{8}$ O navedenom projektu usp. http://www.rudnicikulture.com/. U projekt su uključeni sljedeći umjetnički kolektivi: L.A.E. XXI, Labin i Polygon, Zagreb (Hrvatska), Manifest, Prijedor (BiH), Tera Nostra, Mojkovac (Crna Gora), Remont, Beograd (Srbija), Loke Studio, Zagorje ob Savi i Delavski Dom Trbovlje (Slovenija), Kult-tranzen, Strumica (Makedonija) i Kosova në Lëvizje, Priština (Kosovo). Rudnici kulture u međuvremenu su od platforme postali međunarodna organizacija.

9 Branka Cvjetičanin, „Narativi krapanskog kulturnog krajolika. Umjetničko-istraživački projekt centra Polygon posvećen Istarskim rudnicima u Krapnu i okolici,“ Zarez, 2015, pristupljeno 26. srpnja 2020, http://www.zarez.hr/clanci/narativi-krapanskog-kulturnogkrajolika.

${ }^{10}$ U knjizi, među ostalim, Xena bilježi sve navodno marginalne žive skulpture Labina, pa tako spominje i labinskog performera pod imenom Euro Laube - Keko, ističući kako je riječ o jedinom labinskom filozofu koji je shvatio supstanciju Labina, „tj. dominirajuću špageti western strukturu avetinjskoga grada. Filmografija spomenutog umjetnika bazira se na odistinski domaćoj Zerebanjek-filozofiji gdje Euro Laube tzv. Keko jest Scheriff koji nadljudskim snagama bori se protiv zlih i prljavih neprijatelja Labina i labinštine" (Xena L. Županić, Yztok Zapada (Labin: vlastita naklada, 2014)).

${ }^{11}$ Županić, Yztok Zapada. Usp. Suzana Marjanić, „Vokoperformansi - Neda Šimić-Božinović i Xena L. (Loredana) Županić: glumice i umjetnice performansa,“ u Krležini dani
} 
Labinska multimedijalna umjetnica Xena L. Županić, istina, daleko je poznatija na milanskoj kontrakulturnoj sceni, a ovom prigodom mogu još istaknuti da je diplomirala filozofiju i povijest umjetnosti na Filozofskom fakultetu u Zadru, glumu i scenografiju na Scuola di Recitazione Quelli di Grock u Milanu te glumu na Accademia D'Arte Drammatica di Milano. Nadalje, bavila se modom (imala je vlastiti brend Hermetika) i sudjelovala u revijama najvećih svjetskih modnih dizajnera i dizajnerica; glumi u kazalištu (gdje posebno ističe suradnju s glumcem Carmelom Beneom koji je utjecao na njezine vokoperformanse), igranim filmovima (G. Salvatores), radijskim i TV-dramama, videospotovima; snimila je četiri diskoalbuma za Emi Italia, dva s Metal Guruom; 2002. osnovala je i vodila kulturni centar Ludiialydis u Milanu; radila je za talijansku televiziju („Markette“, P. Chiambretti, la 7, Mediaset, Rai Uno itd.), izlagala na samostalnim i skupnim izložbama (Venecijanski bijenale, Tanzquartier Beč, Harald Szeemann). Godine 2002. postaje članica Labin Art Expressa i Metal Gurua. Danas djeluje kao multimedijalna umjetnica, izvodi vlastite performanse, kazališne predstave kao redateljica i akcije. Imala je bitnu ulogu u programu Labin Art Expressa, odnosno, kako je to istaknula njezina kći Persefone Zubčić, Xena L. Županić svjesno unosi primordijalni majčinski element u dva osnovna projekta Labin Art Expressa s kojima je donedavno surađivala - Podzemni grad XXI te Začeće i rođenje djeteta-boga-umjetnika Heroja 21. st., koji se otkrivaju pod znakom dvaju elemenata - lunarnog (silazak u Podzemni grad i začeće) i solarnog (rođenje heroja-umjetnika koji nastavlja dnevni život). Povlačenjem i silaskom u utrobu Podzemnoga grada, u njezinoj interpretaciji, umjetnici L.A.E.-a gube svoje spolne konotacije postajući androgina noćna bića čije fizičko obličje i vremensko trajanje ne ukazuju na neki precizan i trajan oblik. ${ }^{12}$

\footnotetext{
u Osijeku 2017. Redatelji i glumci hrvatskoga kazališta. Prvi dio, ur. Martina Petranović, Boris Senker i Anamarija Žugić (Zagreb - Osijek: Zavod za povijest hrvatske književnosti, kazališta i glazbe HAZU, Odsjek za povijest hrvatskog kazališta - Hrvatsko narodno kazalište u Osijeku - Filozofski fakultet u Osijeku, 2018), 201-212.

${ }^{12} \mathrm{U}$ zamišljenom multimedijalnom performansu Carska Rez-ba umjetnica ukazuje na misterij tjelesno-duhovne preobrazbe ženskoga tijela. Postupno zaokrugljivanje, sferoidalizacija ženske trbušne šupljine, ukazuje na $U r$-Oblik, primordijalnu sferu iz koje sve potječe i sve se rađa. U okviru svojih vokoperformansa umjetnica zvučno prati krik rađanja kao vječnu traumu rođenja..., kako je to koncipirala u okviru svojih videoperformansa izloženih na izložbi o reproduktivnim pravima u Galeriji Vladimir Bužančić (Zagreb, kustosica Anita Zlomislić) 2017. godine, koja je ujedno i prva izložba o trudnoći što se tiče lokalne scene. U kontekstu navedenoga ističem i videoperformans Živo-tinja u kojemu glasovnim manifestacijama umjetnica ekofeministički postavlja u suodnos lekseme život, žena i životinja te životariti, živo srebro, živa, ujevićevski apostrofirajući „Lijek je lelek srebra i sebra“.
} 
Podsjećam na labinske me(n)talne aberacije na Eurokazu 2005. godine kada smo mogli pogledati dokumentarno-fiktivni performans U-BITI Labin Art Expressa, što ga autorski potpisuju Dean Zahtila i Xena L. Županić. Multimedijalni dvojac Zahtila-Županić uspio je, vjerojatno teškom mukom, okupiti jedanaestero Labinjana, mahom naturščika, koji su pokušali, a po nekima i uspjeli, dramaturgijom kaosa uprizoriti labinske probleme, ili kako navode u programskoj knjižici Eurokaza, riječ je o ,gradu bezizlazne sadašnjosti, karbonizirane prošlosti“, ,gradu anomalija - nekad najbogatiji, a danas najsiromašniji grad u Istri, grad Matije Vlačića i grad umjetnosti, grad s abnormalnim postotkom mentalnih bolesti, narkomana, samoubojstava, grad nespojive mješavine kultura". Ili kao što je Xena apostrofirala u Globusu (1. srpnja 2005) da je „Labin taj koji je U-bio“. Nažalost, zbog scene fellatija, a ne zbog iskaza o činu ubojstva čija je posljedica „otjelotvorenje“ ubojice, ili primjerice Xenina iskaza „Bog je visoko, car je daleko“, što ga je više puta apostrofirala na početku izvedbe, $U$-BITI našao se na naslovnicama nekih naših dnevnih novina. Ili rekapitulacijom Deana Zahtile otprilike dva tjedna nakon eurokazovske izvedbe: „Naime, novinar u Jutarnjem opalio je da je bio fellatio i gotovo svi su to prenijeli, a mi ne želimo navedeno opovrgavati jer doista nije važno je li bio stvaran ili nije bio stvaran fellatio, i apsolutno ne mijenja u toj predstavi ništa." ${ }^{\text {"13 }} \mathrm{U}$ svojoj knjizi Yztok Zapada Xena Županić navodi kako se u klasičnom svijetu čin fellatio označavao glagolom irrumare (dati dojku, dojiti), „onda čitav skandal, graju koja se digla oko čitave predstave (U-BITI, Eurokaz, Zagreb), ne treba čitati kao moralističko prosuđivanje, već kao senzibilnu, tankoćutnu manifestaciju onoga podsvjesnog, arhaičnog, vidljivog stožera u nama na kojem počivaju najvažniji elementi psihičke strukture našega bića“. Osobno smatram da se tom eurokazovskom izvedbom, što se tiče nekih kritičarskih krugova, demonstriralo ono što je npr. Appadurai naveo u vezi s drugošću u antropološkom proučavanju - da su neki Drugi više Drugi od nekih drugih. ${ }^{14}$

Usp. Xena L. Županić, „Miteleuropski sat u srcu Hrvatske“ (razgovarala Suzana Marjanić), Zarez, 22. veljače 2016, pristupljeno 12. svibnja 2019, http://www.zarez.hr/clanci/xena-1-zupanic-miteleuropski-sat-u-srcu-hrvatske.

${ }^{13}$ Suzana Marjanić, Kronotop hrvatskoga performansa: od Travelera do danas (Zagreb: Udruga Bijeli val - Institut za etnologiju i folkloristiku - Školska knjiga, 2014), 1207-1216.

${ }^{14}$ Arjun Appadurai, „Theory in Anthropology: Center and Periphery,“ Comparative Studies in Society and History, sv. 28, br. 2 (1986): 357. 


\section{Izložbeni Labin - Krapan}

U kontekstu industrijske baštine Labina navodim i labinsku izložbu Rudarske uspomene (2008) Kristine Leko koja osim umjetničke dimenzije ima i etnografsku kvalitetu oživljavanja života rudara kao zaboravljene i danas potpuno nevidljive zajednice. S kustosicom Sabinom Salamon, koja je tada bila voditeljica Gradske galerije u Labinu, Kristina Leko organizirala je navedenu izložbu s labinskim rudarima s ciljem oživljavanja rudarske baštine koja svjedoči i o nekadašnjoj multikulturalnosti toga prostora. Izložba je oblikovana kao prošireno dokumentarno kino u suradnji s lokalnom zajednicom. Središnji dio izložbe čini projekcija razgovora s labinskim rudarima, a jedan od problema na koje je izložba ukazala jest činjenica da se Istrijani danas pomalo srame rudarstva. ${ }^{15}$ Tako je dvadesetak bivših rudara na radionicama oživilo uspomene na razdoblje profesionalnog i životnog identiteta, kroz sjećanja, zapise, osobne predmete, fotografije, predmete iz rudnika, rudarske novine, skulpture i dramske tekstove. Pritom je nekoliko labinskih entuzijasta uključilo privatne zbirke o rudarstvu; npr. tu su se našli i predmeti iz zbirke Senada Hujdurovića, rudarskoga sina, kasnije rudara u Labinu, koji je kao invalid rada umirovljen s 38 godina. Na lokalnoj razini navedeni je projekt nastojao revalorizirati bavljenje danas zanemarenom rudarskom tradicijom kao kulturnom baštinom te su ubrzo poslije izložbe neki od sudionika osnovali udrugu za brigu o rudarskoj baštini. Umjetnica navodi i zanimljive detalje iz antropologije solidarnosti rudara, npr. često su nedjeljom radili udarnički, natjecali se, besplatno, a zarada je išla za bolnicu, školu ili pak za tunel Učka. Što se tunela tiče, rudarima je obećano da će imati slobodan prolaz kroz njega. Tunel je prodan, tj. dan u koncesiju francuskoj tvrtki, i nitko ne pamti koliko su nedjelja rudari dali tunelu, nitko se ne sjeća danog obećanja. ${ }^{16}$ Suočena sa slučajem u Krapnu tijekom rada na projektu Underground city XXI, na mapiranju podzemnih i nadzemnih objekata rudnika Labinštine, u suradnji s Labin Art Expressom XXI

\footnotetext{
${ }^{15}$ Kristina Leko, „Uredi za popravljanje ustava“ (razgovarala Suzana Marjanić), Zarez, br. 278 (2010): 36-37; „Rudarske uspomene, 2008.,“ pristupljeno 26. srpnja 2020, http://otvorenilikovnipogon.org/projekti/rudarske-uspomene.html.

${ }^{16}$ Kako navodi autorica: „U knjižici o tom projektu, koja je upravo završena, nalazi se i reprint rudarskih novina iz 1959. koje, među ostalim, navode, Čitanjem se uči, učenjem se stječe znanje.... Polazilo se od toga da rudare treba i obrazovati, te se netko o tome brinuo, radio im novine. Takvo što danas u potpunosti izostaje. Tko danas postavlja pitanje npr. o mogućim kulturnim potrebama žena koje rade u tekstilnoj industriji?““ (Kristina Leko, „Uredi za popravljanje ustava,“ $36-37)$.
} 
multimedijalna umjetnica Branka Cvjetičanin osniva 2012. godine Regrutni centar za umjetnike Pozzo Franz u Krapnu kako bi unijela matricu umjetnosti i kulture u to potpuno zanemareno selo. Različiti programi rada sa zajednicom i u zajednici traju neprekidno od 2012. do 2020. godine kada stanovnici Krapna napokon dobivaju pravni status stanovanja koji nije postojao od zatvaranja posljednjeg rudnika. Tijekom ljeta umjetnica stanuje zajedno s lokalnim stanovništvom i dijeli njegove probleme, što njezinu djelovanju u Krapnu i za Krapan svakako daje neosporivu ozbiljnost i težinu. Iako je došla s namjerom da se bavi umjetnošću, odradila je odličan antropološki posao, kako to zamjećuje antropologinja Katarina Lamešić. ${ }^{17}$ Vratiti život jednoj zajednici od koje su svi o kojima je ovisila digli ruke i biti njezin glas kada je nitko ne želi čuti nije mali pothvat. Danas Krapan ima svoj ljetni festival Krapan EU Kapital, festival suvremene socijalne, kulturne i umjetničke prakse s fokusom na urbanizmu s posebnim potrebama u ekstremnim životnim uvjetima, koji uključuje kulinarske radionice i prezentacije, umjetničke performanse, dječje radionice i ljetno kino, na kojem sudjeluju međunarodni umjetnici i s drugim oblicima participativnih suvremenih kulturnih i umjetničkih praksi. ${ }^{18}$ Kao što zamjećuje Branka Cvjetičanin, Krapan, jedno od naselja Općine Raša, smješten je u krajnjem sjeveroistočnom dijelu raške kotline (nekadašnjeg Krapanskog jezera) i prema popisu iz 2001. broji 203 stanovnika. Stalna eksploatacija kamenog ugljena u Krapnu počinje 1785, što Krapan stavlja u kontekst i vrijeme europske industrijske revolucije 1760-ih. Krajem 19. st. u Krapan i dalje pristižu investicije, te se gradi niz stambenih zgrada; nastava u osnovnoj školi drži se na hrvatskom i njemačkom jeziku, a tek 30-ih godina 20. stoljeća otkrivaju se nove žile crnog ugljena, šire se i stvaraju novi lokaliteti koji u rudarstvu podrazumijevaju i cjelokupnu nadzemnu infrastrukturu, što je trenutak nastanka Raše i Podlabina.

Sličnom se metodologijom rada koristi i multimedijalni umjetnik Marijan Crtalić (1968-2020) u svome dugogodišnjem projektu Nevidljivi Sisak sa sisačkom Željezarom, koji izvodi virtualno i realno. U okviru projekta umjetnik je 2014. godine osnovao Festival Željezara (lokalnim je vlastima projekt predložio 2007. godine) koji je okupio eminentne predstavnike i predstavnice hrvatske i regionalne suvremene

\footnotetext{
${ }^{17}$ Katarina Lamešić, „Branka Cvjetičanin, Delegacija, posjet Raši, Krapnu i Labinu, 20. svibnja 2017., izložba: Galerija Prozori, 6. - 20. lipnja 2017.“" 229-231.

${ }^{18}$ Godine 2016. navedeni je festival postao dio programa Europske prijestolnice kulture Rijeka 2020.
} 
umjetnosti, aktivističke udruge i pojedince te ponajbolje glazbene izvođače s područja tzv. nezavisne glazbene i kulturne scene. Bio je to svojevrstan memento i na umjetnikovu socijalno angažiranu izložbu Nevidljivi Sisak: fenomen Željezara (2009). U okviru projekta Nevidljivi Sisak umjetnik istražuje taj grad u nekoliko slojeva - od arheoloških ostataka do predmeta i mjesta koja svjedoče i o nekim ne tako davnim vremenima i o sadašnjosti, sa željom da se rehabilitira kulturna baština Siska. Povezivanje umjetničkog koncepta i radništva u spomenutoj izložbi Crtalić je ostvario na temelju činjenice da je u sklopu Željezare Sisak početkom 1970-ih bila pokrenuta likovna kolonija (1971-1990) u kojoj su kulturni radnici i radnici Željezare stvarali međusobno surađujući. Pritom su se njihova djela, kako navodi, poklanjala radnicima, a umjetnici su dobivali honorare za njih, ,i svi su bili sretni i zadovoljni“, recimo. U dokumentarnom filmu Industrijski raj umjetnik intervjuira radnike koji svjedoče o povijesnom iskustvu - vremenu nastanka skulptura u umjetničkoj koloniji i o današnjem vremenu, kada se mnogim skulpturama iz tog „muzeja na otvorenom“ ne zna ni autor ni godina izrade, a djeca, neopterećena simboličkim nasljeđem, koriste se njima za igru. Umjetnik sličnom strategijom kojom se poslužila Kristina Leko ${ }^{19}$ u projektu/izložbi Rudarske uspomene okuplja na jednom izložbenom mjestu dokumentarni materijal (arhivske fotografije, izreske iz novina, dokumente), kontrapunktirajući ga aktualnom trenutku koji pokazuje da je od te radničko-umjetničke suradnje preostalo svega tridesetak oštećenih skulptura na javnim površinama radničkog naselja Željezare (naselje Caprag). Nažalost, slična je sudbina zadesila i radnike Željezare - te nekad najveće tvornice u ovom dijelu Europe - čiji se broj smanjio s nekadašnjih (otprilike) 14000 na svega 1000 zaposlenika, a danas na svega stotinjak radnih mjesta. Željezaru Sisak preuzela je 2007. godine američka korporacija CMC koja se obvezala zadržati svih 1416 radnika najmanje tri godine, ali već 2008. svjedočili smo otpuštanju radnika i prebacivanju svih strojeva iz Željezare u američke pogone. Upravo je

\footnotetext{
${ }^{19}$ Svi navedeni umjetnici i umjetnice koriste se etnografskim metodama u svome radu, pa tako npr. Marijan Crtalić, kako zamjećuju kulturni antropolozi Tomislav Pletenac i Sanja Potkonjak, započinje „svoj projekt etnografskim prikupljanjem građe na temu socijalizma u Sisku, odlascima ,na teren' fotografira i evidentira skulpture koje zatječe u neposrednoj okolici Željezare Sisak, kao preostatak nekadašnje socijalističke umjetničke likovne kolonije“ (Tomislav Pletenac i Sanja Potkonjak, „Kada spomenici ožive - ,umjetnost sjećanja“ u javnom prostoru,“ Studia ethnologica Croatica, sv. 23 (2011): 12); Marijan Crtalić, „Sisačka Željezara bila je mecena umjetnicima,“ Večernji list, 20. studenoga 2009, pristupljeno 26. srpnja 2020, http://www.vecernji.hr/vijesti/sisacka-zeljezara-bila-je-mecena-umjetnicima-clanak-53715.
} 
ta snažna priča o Sisku dokument koji svjedoči o osiromašenju jednog od nekad najrazvijenijih gradova bivše države.

\section{Zaključno o mogućoj relaciji Labin - Katowice}

Labin u kontekstu istarskih ugljenokopa možemo urbanoantropološki usporediti s Katowicama u kojima je 2018. godine održana najvažnija UN-ova konferencija o klimatskim promjenama nakon Pariškog sporazuma 2015. godine..$^{20} \mathrm{Za}$ razliku od Katowica, koje su na izniman način nekadašnji industrijski kompleks prenamijenile u rudnike kulture, Labin na tome još uvijek radi, gašenjem rudarskih jama potkraj prošlog stoljeća, a kada se početkom 2000-tih pojavio novi ideološki konstrukt „kreativne/kulturne industrije“, koji je odjeknuo poput nove religije kulturne i umjetničke scene Zapada, počinje nova faza u razvoju rudnika u kojoj se tražio način da se postojeća infrastruktura iskoristi za kulturne potrebe grada i regije. Značajnu ulogu u tome imaju civilne udruge i inicijative poput Labin Art Expressa i Branke Cvjetičanin kao voditeljice istraživačkog projekta „Regrutni centar za umjetnike - Pozzo Franz", koji je tematski i geografski lociran u Krapnu nedaleko od Raše. To je mjesto najstarijeg ulaska u jamu i prva nadzemna infrastruktura rudarskog kompleksa Labina i Raše, danas zaboravljeno naselje s administrativno i pravno nereguliranim statusom u kojem živi dvanaest obitelji. Tako je prvi „Polygon - regrutni centar za umjetnike“ pokrenut 2012. godine u Krapnu i nazvan prema krapanskom toponimu - Pozzo Franz.

\footnotetext{
${ }^{20}$ Katowice su odabrane za najvažniju UN-ovu konferenciju o klimatskim promjenama nakon Pariškog sporazuma 2015. godine kao jedan od najzagađenijih dijelova Europe zbog eksploatacije ugljena, odnosno zbog svoje tranzicije iz rudarsko-industrijskoga u moderno industrijsko, gospodarsko, tehnološko i kulturno središte. Glavni cilj Pariškog sporazuma (Konferencija UN-a o klimatskim promjenama COP21) iz 2015. godine bilo je smanjenje emisije stakleničkih plinova kao posljedice upotrebe fosilnih goriva (treset, ugljen, nafta, zemni plin) te ograničenje rasta globalne temperature na razinu između 1,5 i 2 stupnja Celzijeva u odnosu na predindustrijsku razinu; HINA, „U nedjelju počinje nova konferencija o klimi: ,Samo nekim čudom možemo uspjeti“," pristupljeno 2. studenoga 2016, https:// www.index.hr/vijesti/clanak/u-nedjelju-pocinje-nova-konferencija-o-klimi-samo-nekimcudom-mozemo-uspjeti/2046577.aspx.

Marzena Lamparska, „Post-industrial Cultural Heritage Sites in the Katowice conurbation, Poland,“ Environmental \& Socio-economic Studies, sv. 1, br. 2 (2013): 36-42, Agnieszka Sobala-Gwosdz i Krzysztof Gwosdz, „Katowice effect"? Regeneration of the site of the former Katowice coal mine through prestige cultural projects," Urban Development Issues, sv. 56, br. 4 (2017): $27-40$.
} 


\section{Literatura}

Appadurai, Arjun. „Theory in Anthropology: Center and Periphery.“ Comparative Studies in Society and History, sv. 28, br. 2 (1986): 356-361.

Crtalić, Marijan. „Sisačka Željezara bila je mecena umjetnicima.“Večernji list, 20. studenoga 2009. Pristupljeno 26. srpnja 2020. http://www.vecernji.hr/vijesti/ sisacka-zeljezara-bila-je-mecena-umjetnicima-clanak-53715.

Cvjetičanin, Branka. „Narativi krapanskog kulturnog krajolika. smjetničko-istraživački projekt centra Polygon posvećen Istarskim rudnicima u Krapnu i okolici.“ Zarez, 2015. Pristupljeno 26. srpnja 2020. http://www.zarez.hr/ clanci/narativi-krapanskog-kulturnog-krajolika.

HINA. „U nedjelju počinje nova konferencija o klimi: ,Samo nekim čudom moŽemo uspjeti،““ Pristupljeno 2. studenoga 2016. https://www.index.hr/vijesti/ clanak/u-nedjelju-pocinje-nova-konferencija-o-klimi-samo-nekim-cudommozemo-uspjeti/2046577.aspx.

Labin Art Express: 1992.-2012. (predgovor Viktor Zahtila, pogovor Branko Franceschi, autori fotografija Rajko Tasić i sur.). Labin: Labin Art Express XXI, 2013.

Lamešić, Katarina. „Branka Cvjetičanin, Delegacija, posjet Raši, Krapnu i Labinu, 20. svibnja 2017., izložba: Galerija Prozori, 6. - 20. lipnja 2017.“ Narodna umjetnost, sv. 54, br. 2 (2017): 229-231.

Lamparska, Marzena. „Post-industrial Cultural Heritage Sites in the Katowice conurbation, Poland.“ Environmental \& Socio-economic Studies, sv. 1, br. 2 (2013): 36-42.

Leko, Kristina. „Uredi za popravljanje ustava“ (razgovarala Suzana Marjanić). Zarez, br. 278 (2010): 36-37.

Marjanić, Suzana. „Labinske me(n)talne aberacije.“ Zarez, br. 159-160 (2005): 44.

Marjanić, Suzana. Kronotop hrvatskoga performansa: od Travelera do danas. Zagreb: Udruga Bijeli val - Institut za etnologiju i folkloristiku - Školska knjiga, 2014.

Marjanić, Suzana. „Izvedba undergrounda.“ Zarez, br. 383 (2014): 41.

Marjanić, Suzana. „Vokoperformansi - Neda Šimić-Božinović i Xena L. (Loredana) Županić: glumice i umjetnice performansa."U Krležini dani u Osijeku 2017. Redatelji i glumci hrvatskoga kazališta. Prvi dio, uredili Martina Petranović, Boris Senker i Anamarija Žugić, 201-212. Zagreb - Osijek: Zavod za povijest hrvatske književnosti, kazališta i glazbe HAZU, Odsjek za povijest hrvatskog kazališta - Hrvatsko narodno kazalište u Osijeku - Filozofski fakultet u Osijeku, 2018.

Matošević, Andrea. Pod zemljom: antropologija rudarenja na Labinštini u XX. stoljeću. Zagreb: Institut za etnologiju i folkloristiku - Sveučilište Jurja Dobrile u Puli, 2011.

Pletenac, Tomislav, i Sanja Potkonjak. „Kada spomenici ožive - ,umjetnost sjećanja‘ u javnom prostoru.“ Studia ethnologica Croatica, sv. 23 (2011): 7-24.

„Rudarske uspomene, 2008.“ Pristupljeno 26. srpnja 2020. http://otvorenilikovnipogon.org/projekti/rudarske-uspomene.html. 


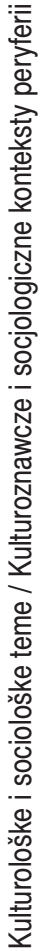

Sobala-Gwosdz, Agnieszka, i Krzysztof Gwosdz. „Katowice effect"? Regeneration of the site of the former Katowice coal mine through prestige cultural projects.“ Urban Development Issues, sv. 56, br. 4 (2017): 27-40.

Županić, Xena. L. Yztok Zapada. Labin: vlastita naklada, 2014.

Županić, Xena L. „Miteleuropski sat u srcu Hrvatske“ (razgovarala Suzana Marjanić). Zarez, 22. veljače 2016. Pristupljeno 12. svibnja 2019. http://www.zarez. $\mathrm{hr} /$ clanci/xena-l-zupanic-miteleuropski-sat-u-srcu-hrvatske.

\section{Fotoprilozi}

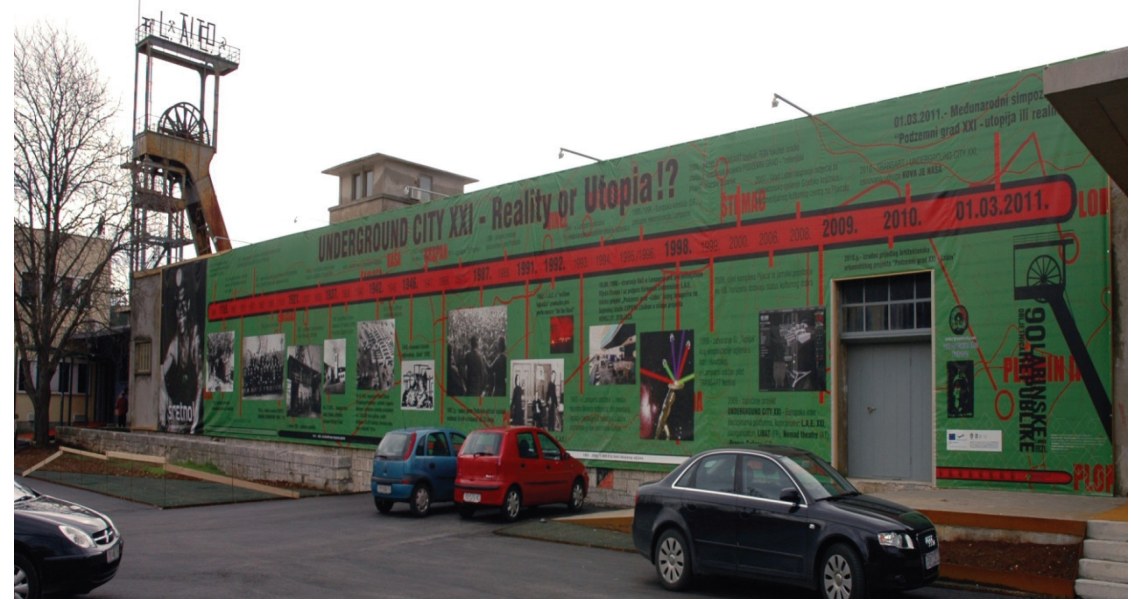

Fotografija 1: Fotoarhiv L.A.E.-a: L.A.E. i KuC Lamparna ${ }^{21}$

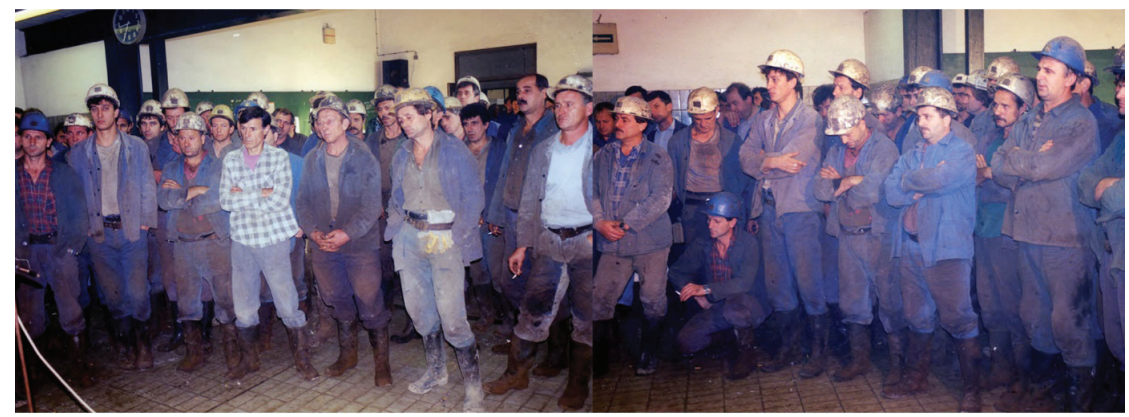

Fotografija 2: Iz arhive projekta Rudarske uspomene, Labin, 2008, projekt Kristine Leko u suradnji s bivšim rudarima i njihovim obiteljima. ${ }^{22}$

\footnotetext{
${ }^{21}$ Preuzeto s internetske stranice www.lae.hr uz dozvolu Deana Zahtile.

22 Fotografija preuzeta $\mathrm{s}$ internetske stranice http://otvorenilikovnipogon.org/projekti/rudarske-uspomene.html uz dozvolu Kristine Leko.
} 


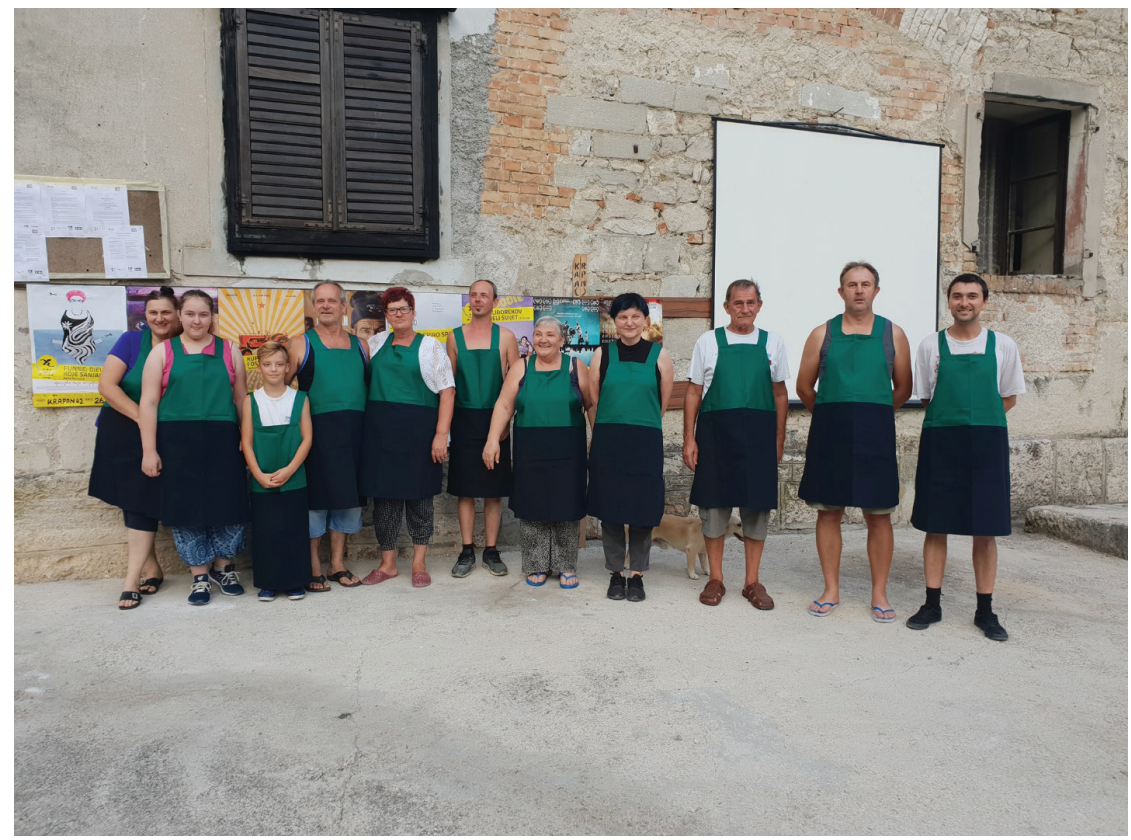

Fotografija 3: Polygonov arhiv, Regrutni centar za umjetnike Pozzo Franz, Krapan (2018)

\section{Labin, or Underground Performance as a Mode of Resistance to Isolation, Periphery}

Summary: Using the example of the town of Labin in Istria, I demonstrate how isolation, the so-called periphery, can also serve as an expression of resistance in a cultural niche. The collective Labin Art Express (L.A.E., initiated by Dean Zahtila, late Krešimir Farkaš, Graziano Kršić) is the initiator of the fundamental L.A.E. project Underground City XXI - independent underground Labin cultural city as an alternative to the existing above-ground, heteronomous Labin, i.e. the creation of a real city $150 \mathrm{~m}$ below the earth's surface - in underground halls and tunnels, carved in solid rock, connecting Labin, Raša, Plomin and Rabac, with streets, bars, galleries, swimming pools, playgrounds for children, shops, restaurants, the Museum of Mining and Industry of Istria.

Thereby we can compare Labin in terms of urbanity and anthropology with the town of Katowice, which in 2018 was selected to host the most significant UN Climate Change Conference, following the 2015 Paris Agreement. Katowice were chosen as one of Europe's most polluted sites due to the exploitation of coal i.e. the transition of the aforementioned town from a mining and industrial site to a modern industrial, economical, technological and cultural centre.

Keywords: Labin Art Express, project Underground City XXI, anthropology of mining, Katowice, periphery as a mode of resistance

${ }^{23}$ Fotografiju je ustupila umjetnica Branka Cvjetičanin, autorica navedenoga projekta. 